\title{
Gelatinous transformation of the bone marrow complicated by self induced starvation
}

\author{
H. Singh", S. Singh ${ }^{* *}$, M.S. Gupta ${ }^{*}$ R. Jindal ${ }^{* *}$, R. Aggarwal ${ }^{*}$
}

\begin{abstract}
Abstrak
Transformasi sumsum tulang gelatin jarang didapatkan. Kasus ini berhubungan dengan penyakit yang berat dan malnutrisi. Dilaporkan satu kasus T STG dengan tinjauan pustaka. (Med J Indones 2002; 11: 104 -5)
\end{abstract}

\begin{abstract}
Gelatinous bone marrow transformation (GMT) is rare. It has been found to be associated with severe illnesses and malnutrition (rarely). A case report highlighting GMT as "starvation marrow" along with review of literature is being presented. (Med JIndones 2002; 11: 104 -5)
\end{abstract}

Keywords: malnutrition, bone marrow, gelatinous transformation

Gelatinous bone marrow transformation (GMT) is a rare but a nonspecific disorder of bone marrow associated with generalised severe illnesses. ${ }^{1}$ Within last 3 decades, approximately only about 20 papers (mainly case reports) have been published. ${ }^{\text {' }}$ A case report of GMT associated with selfinduced starvation/ malnutrition is being presented.

\section{CASE REPORT}

A 70 year old widower and ex-serviceman presented with gradually increasing weakness and pedal oedema. To begin with 6 months back patient started complaining of weakness accompanied with headache especially in evening hours. This was not accompanied with fever, cough with expectoration, blood loss, jaundice, loss of appetite or urinary trouble. Later, patient started complaining of increased frequency of loose stools (containing both faecal matter and mucus) but without any accompanying abdominal pain or blood in stools. Still later patient started complaining of pedal oedema especially evening hours which was not accompanied with dyspnoeal distension abdomen. Patient also lost weight about

Department of Medicine* \& Pathology**, Pt. B.D. Sharma, PGIMS, Rohtak - 124001 Haryana, India
$30 \%$ (approx.) of his original. Patient had been a vegetarian, non-alcoholic but his meal pattern was irregular due to personal family reasons as he was staying alone. On clinical examination, there was evidence of severe anaemia, bilateral pedal oedema but vitals were normal. His nourishment was poor as there was evidence of Bitot's spots in eyes, chelosis and glossitis in buccal cavity, loss of subcutaneous fat as also muscle mass and his body weight was 22 percentile less of expected. There was no evidence of jaundice, bleeding gums, purpuric spots or sternal tenderness. The cardiovascular, respiratory, abdomen (including per rectal) and nervous system examination was essentially normal. Investigations revealed : haemoglobin $3.8 \mathrm{~g} / \mathrm{dl}$; TLC-4200/mm3; DLC$\mathrm{P}_{60} \mathrm{~L}_{36} \mathrm{M}_{2} \mathrm{E}_{2}$; platelets - adequate; $\mathrm{PBF}$ showed evidence of dimorphic anaemia with no evidence of parasite. ESR was $50 \mathrm{~mm}$ in first hour (by Wintrobe method), urine and stool examinations were normal. Serum protein was $4.4 \mathrm{~g} \%$ with $\mathrm{A}: \mathrm{G}$ ratio 1.0 , while other biochemical tests - serum creatinin, blood sugar, SGOT/SGPT, serum bilirubin (direct/indirect), serum alkaline phosphatase were all essentially normal. Serology for HIV and Australia antigen were negative. Ultrasound for abdomen, X-ray chest (PA view), X-ray skull (lateral view) and pelvis (AP view) were essentially normal while Barium meal study revealed early evidence of malabsorption but without any evidence of stricture or adhesion as also the ileocaecal junction was normal. 
Bone marrow aspiration was performed. The smears were dificult to spread. Low magnification revealed abundant marrow particles which had reduced fat and hematopoietic cells. The marrow cells were replaced by a pink purple substance which had homogenous gelatinous appearance. On May-Graunwald-Giemsa' staining (Figure 1), this substance stained strongly positive with Alcian-blue at $\mathrm{pH} 2.5$ and was weakly staining with Periodic acid - schiff stain.

Based on above profile of absence of inflammatory markers and vegetarian meal pattern that too irregular due to geriatric and widower status, a clinical probability of self induced starvation/malnutrition leading to vitamin and protein deficiency and GMT changes in bone marrow was made. Patient was put on supplementation vitamin $\mathrm{A}$, folate and $\mathrm{B} 12$ along with high protein diet. Patient started improving as hemoglobin started showing a gradual rise. But at 6 weeks, patient lost follow-up and so a repeat bone marrow aspiration of biopsy could not be attempted.

\section{DISCUSSION}

Gelatinous bone marrow transformation (GMT) is a rare disorder of unknown pathogenesis, characterized by fat cell atrophy, focal loss of hematopoietic cells and deposition of extracellular gelatinous substances, which histochemically are mucopolysacchride rich in hyaluronic acid. ${ }^{1}$ It was first identified in patents suffering from prolonged starvation with cachexia and so was also termed as "starvation marrow" or "serous (fat) atrophy", 2,3 GMT has been found associated with other disorders. In one series tumours (37.5\%), malnutrition $(16.8 \%)$, infection $(11.8 \%)$, maldigestion $(10.1 \%)$, heart failure $(7.0 \%)$, metabolic disorders $(5.4 \%)$ while others including renal failure and psychosis $(11.4 \%) .{ }^{1}$ Weight loss and anaemia was a consistent sign seen with GMT. ${ }^{1-3}$

Review of literature reveals that GMT is associated with condition leading to malnutrition like anorexia nervosa, starvation, chronic alcoholism, vegetarianism, psychotic disorders and geriatric patients (with disturbed food intake). ${ }^{2,45}$ The pathogenesis and possible function of GMT remains unclear. ${ }^{1}$ It is suggested that hyaluronic acid (not physiologically present) may be the substance to replace fat cells in the marrow that are used in such catabolic / starving states of disease. ${ }^{2,3,5}$ GMT lesions may occur in the background of severe weight loss but most patents with chronic wasting disease do not show GMT; so additional factors besides fat cell mobilization may be necessary for development of GMT. ${ }^{1}$ A complete disappearance of GMT changes in patients of anorexia nervosa and in experimentally starved animals after normalization of nutritional status indicates its reversible state. ${ }^{2}$

\section{REFERENCES}

1. Bohm J. Gelatinous transformation of the bone marrow the spectrum of underlying diseases. Amer J Surg Pathol 2000; 24 (1):56-65.

2. Nonaka D, Tanaka M, Takaki $\mathrm{K}$, Umeno $\mathrm{M}$, Okmura $\mathrm{T}$, Taketa $\mathrm{H}$. Gelatinous bone marrow transformation complicated by self induced malnutrition. Acta Haematol 1998; 100:88-90.

3. Seaman JP, Kjeldesberg CR, Linker A. Gelatinous transformation of the bone marrow. Hum Pathol 1978; 9:685-92.

4. Tavassoli M, East Lund DT, Yam LT, Neiman RS, Finkel $\mathrm{H}$. Gelatinous transformation of the bone marrow is prolonged selfinduced starvation. Scand J Haematol 1976; 16:311-9.

5. Basu S, Marwaha N, Ahluwalia M. Gelatinous transformation of bone marrow. JAPI 2001; 29:674-5.

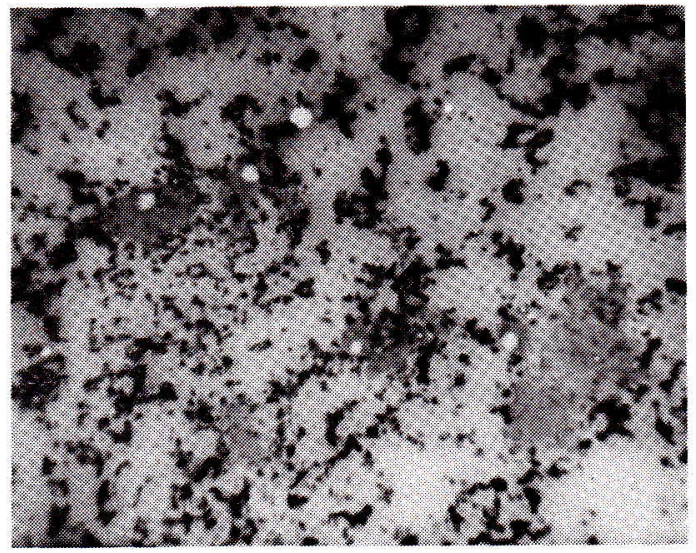

Figure 1. Marrow particles replaced by homogenous substance (MGG $x$ 100) 